\title{
Radial Growth of Eurasian Species of Five-Needle Pines in the Clone Archive in the South of the Tomsk Oblast
}

\author{
Oleg V. Khutornoy*, \\ Eugeniya A. Zhuk and Anatoly Yu. Bocharov \\ Institute of Monitoring of Climatic \\ and Ecological Systems SB RAS \\ 10/3 Academichesky, Tomsk, 634055, Russia
}

Received 16.04.2018, received in revised form 26.06.2018, accepted 17.07.2018

The aim of the work was to analyze intra- and interspecific variations in radial growth dynamics of vegetative progeny from three Eurasian 5-needle pine species (Pinus sibirica Du Tour, P. koraiensis Siebold\&Zucc., P. cembra L.). The object of the study was the 21-year-old vegetative progeny from six Siberian stone pine ecotypes, three Korean pine ecotypes, and one Swiss stone pine ecotype created by grafting the scions from parental trees on the local Siberian stone pine rootstock, which were grown under similar conditions in the south of the Tomsk Oblast, Russia. The variation among the species was quite substantial: radial increment of the Swiss stone pine was almost twice as great as that of the Siberian stone pine, and radial growth of the Korean pine was intermediate. The Siberian stone pine had the highest level of intraspecific variation, and the Korean pine had a lower level. In general, the annual ring width of both species decreased from the southern ecotype to the northern ecotype. Strong incompatibility was observed between scion and rootstock when the Korean pine was grafted on the Siberian stone pine; the other combinations were quite compatible. The interannual variations in the radial increment were determined by the local environmental and climatic conditions rather than by the origin of the parent trees. All three species showed a significant positive correlation between the residual growth indices and the April temperature and the July precipitation.

Keywords: vegetative progeny, Siberian stone pine, Korean pine, Swiss stone pine, radial increment, temperature, precipitation.

Citation: Khutornoy O.V., Zhuk E.A., Bocharov A.Yu. Radial growth of Eurasian species of five-needle pines in the clone archive in the south of the Tomsk Oblast. J. Sib. Fed. Univ. Biol., 2018, 11(3), 260-274. DOI: 10.17516/1997-1389-0070.

(C) Siberian Federal University. All rights reserved

This work is licensed under a Creative Commons Attribution-NonCommercial 4.0 International License (CC BY-NC 4.0).

* Corresponding author E-mail address: hutol@rambler.ru 


\title{
Радиальный рост евроазиатских видов 5-хвойных сосен в клоновом архиве на юге Томской области
}

\author{
О.В. Хуторной, Е.А. Жук, А.Ю. Бочаров \\ Институт мониторинга климатических \\ и экологических систем СО РАН \\ Россия, 634055, Томск, пр. Академический, 10/3
}

Целью работы было проанализировать внутри- и межвидовое разнообразие по динамике радиального роста у вегетативного потомства трех евроазиатских видов 5-хвойных сосен (Pinus sibirica Du Tour, P. koraiensis Siebold\&Zucc., P. сетbra L.). Объектом исследования послужило 21-летнее вегетативное потомство 6 экотипов кедра сибирского, 3 экотипов кедра корейского и 1 экотипа кедра европейского, созданное методом прививки черенков от материнских деревьев на местный подвой кедра сибирского и выращенное в однородных условиях на юге Томской области. Различия между видами были довольно существенны: радиальный прирост у кедра европейского был почти в 2 раза больше, чем у кедра сибирского, а кедр корейский имел промежуточные значения радиального роста среди трех видов. Кедр сибирский обладал самым высоким уровнем внутривидовой дифференциации, кедр корейский - несколько меньшим. В целом, у этих видов радиальный прирост уменьшался от южного экотипа к северному. Наблюдалась довольно сильная несовместимость привоя и подвоя у прививок кедра корейского на кедр сибирский, у остальных вариантов прививок несовместимости практически не было. Погодичная изменчивость прироста в большей степени зависела от местных условий среды и климата, чем от места происхождения материнских деревьев. Все три вида показали достоверную положительную связь остаточных индексов прироста с температурой апреля и осадками июля.

Ключевые слова: вегетативное потомство, кедр сибирский, кедр корейский, кедр европейский, радиальный прирост, температура, осадки.

\section{Введение}

Древесные виды с большими ареалами, как правило, обладают определенным уровнем внутривидовой изменчивости, которая позволяет им адаптироваться к конкретным условиям среды и наиболее полно использовать ее ресурсы. Одним из основных методов исследования внутривидовой дифференциации является исследование ex situ, когда семенное или вегетативное потомство деревьев из различных частей ареала выращивается в однородных условиях. Благодаря таким экспериментам были выявлены основные за- кономерности эколого-географической изменчивости у многих хвойных видов. Было установлено, что в среднем прирост у деревьев из популяций из холодных местообитаний ниже (Oleksyn et al., 2001; Isik et al., 1999; Chuine et al., 2006), а высота и диаметр ствола меньше, чем у деревьев из теплых местообитаний (Savva et al., 2007; Zhuk, Goroshkevich, 2018).

Большая часть работ по внутривидовой изменчивости хвойных видов посвящена географической изменчивости признаков, характеризующих устойчивость и скорость роста. 
Радиальный рост дерева - важный показатель продуктивности, на который влияет множество факторов среды, поэтому ему посвящен довольно большой пласт исследований. Во многих работах показано влияние климата на радиальный рост деревьев в естественных древостоях, которое почти для всех изученных видов оказалось довольно существенным. В частности, для Pinus nigra J.F. Arnold (Amodei et al., 2013) и P. cembra L. (Pfeifer et al., 2005) была установлена связь радиального роста с уровнем осадков весны и лета и с теплообеспеченностью лета и осени, для $P$. cooperi Blanco - с осадками и теплообеспеченностью зимы (Pompa-García et al., 2013), причем связь с климатическими переменными часто варьирует в зависимости от конкретного местообитания (Bogino et al., 2009; Bhuta et al., 2009).

Исследования внутривидовой дифференциации по радиальному росту, проведенные на географических культурах, менее распространены. Такие исследования проводились как для семенного, так и для вегетативного потомства. На примере семенного потомства P. contorta Dougl. было установлено, что на радиальный рост влияют среднегодовая температура и количество летних осадков, однако величина отклика на различные климатические переменные зависит от происхождения популяции и района проведения эксперимента (McLane et al., 2011). На примере $P$. banksiana Lamb. было показано, что наибольшее влияние на радиальный рост имеет количество осадков июля, при этом величина отклика не зависела от происхождения популяций, хотя абсолютные значения радиального роста различались между популяциями (Savva et al., 2008). У вегетативного потомства часто наблюдается явление несовместимости привоя и подвоя, особенно у гетеропластических прививок, что происходит по причине разной скорости роста привоя и подвоя (Jayawickrama et al., 1991; Савва и др., 2004). Прививки с несовместимостью часто гибнут, а выживают в основном те гетеропластические прививки, у которых темпы роста привоя и подвоя различаются незначительно (Кузнецова и др., 2010), что должно отражаться на показателях радиального роста привоев. Помимо этого, привой и подвой могут иметь разный климатический отклик. Так, в работе Дариковой и др. (2013) было показано, что климатическая компонента в радиальном росте отсутствовала у подвоя сосны обыкновенной и присутствовала у привоя кедра сибирского.

Цель данной работы - проанализировать как внутри-, так и межвидовое разнообразие по динамике радиального роста у вегетативного потомства трех евроазиатских видов 5-хвойных сосен (Pinus sibirica Du Tour, P. koraiensis Siebold\&Zucc., P. cembra L.) и ответить на вопросы: 1) насколько данные виды различаются по величине годичного прироста и динамике роста; 2) как проявляется несовместимость привоя и подвоя у гомопластических прививок кедра сибирского из различных экотипов и у гетеропластических прививок кедра корейского и кедра европейского на кедр сибирский; 3) какие климатические факторы оказывают наиболее сильное влияние на радиальный рост данных видов?

\section{Материалы и методы}

Объектом исследования послужило вегетативное потомство 6 экотипов кедра сибирского, 3 экотипов кедра корейского и 1 экотипа кедра европейского (табл. 1). Черенки были срезаны с материнских деревьев и привиты на местные 4-летние саженцы кедра сибирского весной 1996 г. Привитые деревья были выращены в однородных усло- 
Таблица 1. Характеристика районов происхождения экотипов

Table 1. Characteristics of the sites of ecotype origin

\begin{tabular}{|c|c|c|c|c|c|}
\hline Район & Широта & Долгота & $\begin{array}{c}\text { Высота } \\
\text { над ур. м. }\end{array}$ & Природная зона & $\begin{array}{c}\text { Возраст } \\
\text { материнских } \\
\text { деревьев, лет }\end{array}$ \\
\hline \multicolumn{6}{|c|}{ Кедр сибирский } \\
\hline 1. Уренгой & $65^{\circ} 50^{\prime}$ с.ш. & $78^{\circ} 10^{\prime}$ в.д. & 40 м & $\begin{array}{l}\text { Южная подзона зоны } \\
\text { предтундровых редколесий }\end{array}$ & $100-170$ \\
\hline 2. Ноябрьск & $63^{\circ} 10^{\prime}$ с.ш. & $75^{\circ} 20^{\prime}$ в.д. & $110 \mathrm{~m}$ & $\begin{array}{l}\text { Южная часть северной } \\
\text { подзоны тайги }\end{array}$ & $160-210$ \\
\hline 3. Стрежевой & $60^{\circ} 45^{\prime}$ с.ш. & $77^{\circ} 30^{\prime}$ в.д. & 40 м & $\begin{array}{l}\text { Северная часть средней } \\
\text { подзоны тайги }\end{array}$ & 140 \\
\hline $\begin{array}{l}\text { 4. Виссарионов } \\
\text { бор }\end{array}$ & $58^{\circ} 13^{\prime}$ с.ш. & $84^{\circ} 32^{\prime}$ в.д. & $110 \mathrm{M}$ & $\begin{array}{l}\text { Граница средней и южной } \\
\text { подзоны тайги }\end{array}$ & 350 \\
\hline 5. Тайшет & $55^{\circ} 50^{\prime}$ с.ш. & $98^{\circ} 00^{\prime}$ в.д. & $350 \mathrm{M}$ & Южная тайга & 160 \\
\hline 6. Невьянск & $57^{\circ} 15^{\prime}$ с.ш. & $60^{\circ} 1^{\prime}$ в.д. & $300 \mathrm{M}$ & Подтайга & 120 \\
\hline \multicolumn{6}{|c|}{ Кедр корейский } \\
\hline 7. Известковый & $44^{\circ} 20^{\prime}$ с.ш. & $128^{\circ} 25^{\prime}$ в.д. & $850 \mathrm{M}$ & $\begin{array}{l}\text { Граница кедрово-шир. и } \\
\text { кедрово-темнохвойного поясов }\end{array}$ & 200 \\
\hline 8. Пивань & $50^{\circ} 30^{\prime}$ с.ш. & $137^{\circ} 10^{\prime}$ в.д. & $250 \mathrm{M}$ & $\begin{array}{l}\text { Широколиственно- } \\
\text { темнохвойные подтаежные } \\
\text { леса }\end{array}$ & 200 \\
\hline 9. Горный & $50^{\circ} 45^{\prime}$ с.ш. & $136^{\circ} 25^{\prime}$ в.д. & $600 \mathrm{M}$ & $\begin{array}{l}\text { Нижняя часть лесного пояса } \\
\text { (темнохвойные горнотаежные } \\
\text { леса) }\end{array}$ & 180 \\
\hline \multicolumn{6}{|c|}{ Кедр европейский } \\
\hline $\begin{array}{l}\text { 10. Италия } \\
\text { (Тренто) }\end{array}$ & $46^{\circ} 10^{\prime}$ с.ш. & $10^{\circ} 30^{\prime}$ в.д. & $1800 \mathrm{M}$ & Верхняя часть лесного пояса & 200 \\
\hline
\end{tabular}

виях с размещением $3 \times 6$ м в 9 блоках на Научном стационаре «Кедр» Института мониторинга климатических и экологических систем СО РАН, находящемся в 30 км к югу от Томска, Россия (56² $13^{\prime}$ с.ш., 8451' в.д., 78 м над ур. м., юго-восток Западно-Сибирской равнины, южная тайга). Каждый экотип был представлен 11-19 клонами, каждый клон содержал 5-9 рамет.

Климат района, где проводились исследования, резко континентальный, годовая норма осадков составляет 517 мм, среднегодовая температура минус $0,6^{\circ} \mathrm{C}$, средняя продолжительность безморозного периода 114 дней.

Для сравнительного анализа были использованы привитые деревья кедра сибир- ского шести экотипов (Уренгой, Ноябрьск, Стрежевой, Тайшет, Невьянск и Виссарионов бор), деревья кедра корейского трех экотипов (Известковый, Пивань, Горный) и экотип кедра европейского (Тренто). Каждая группа была представлена пятью деревьями (клонами).

Образцы в виде древесных кернов отбирались приростным буравом по двум радиусам, у шейки корня, ниже зоны срастания прививки в среднем на 10-15 см (привой), и выше прививки в среднем на 5-10 см (подвой). После подготовки буровых образцов (наклейка на рейки, зачистка) измеряли ширину древесных колец с помощью измерительного комплекса LINTAB-5 с пакетом компьютер- 
ных программ TSAP (Rinn, 1996) с точностью 0,01 мм. После получения индивидуальных древесно-кольцевых рядов проводили их перекрестное датирование с помощью сочетания кросс-корреляционного анализа (Holmes, 1983) и графической перекрестной датировки (Douglass, 1919). Надежность такого датирования оценивалась расчетом тесноты связи между такими сериями с пошаговым вычислением коэффициента корреляции при помощи программы COFECHA (Holmes, 1992a). Для выявления связей прироста с климатическими параметрами выполнялась процедура стандартизации этих хронологий с помощью программы CRONOL (Methods..., 1990; Holmes, 1992b).

Индивидуальные индексные серии усреднялись в хронологии. В результате стандартизации получали две серии: стандартную и остаточную. Для каждой хронологии рассчитывали основные статистические характеристики: корреляция, стандартное отклонение, коэффициент чувствительности, доля дисперсии, обусловленная первой компонентой, отношение "сигнала к шуму", автокорреляция первого порядка (Шиятов, 1986; Ваганов и др., 1996); данные характеристики были получены с помощью программы ARSTAN (Cook, 1985).

Для выявления и оценки климатического отклика деревьев использовали среднемесячные показатели по температуре и суммам осадков ближайшей метеостанции (г. Томск), расположенной в 20 км севернее от места сбора образцов. Для расчета коэффициентов корреляции с температурами и осадками брали индексированные значения остаточных хронологий. Корреляционный анализ остаточных хронологий прироста и рядов климатических переменных выполнялся в специализированном пакете Statistica for Windows 5.5.

\section{Результаты}

Индексированные ряды прироста показали значительную корреляцию между деревьями внутри отдельных экотипов (табл. 2). В целом, статистические характеристики подтвердили относительную репрезентативность выборок и наличие общего климатического сигнала. Об этом, в частности, говорили показатели согласованности индивидуальных хронологий (отношение «сигнал-шум» - 4,4$7,5)$ и стандартное отклонение $(0,20-0,29)$. Коэффициенты чувствительности показали низкую межпогодичную изменчивость прироста. Автокорреляция продемонстрировала отсутствие влияния прошлогоднего прироста на текущий.

Абсолютные значения радиального прироста по экотипам кедра сибирского (рис. 1) показали линейный тренд средней ширины годичного кольца и широты происхождения материнских деревьев. Чем севернее происхождение, тем меньше прирост. Единственное исключение - экотип Виссарионов бор, но это может быть связано с большой разницей в приросте между подвоем и привоем у деревьев этого экотипа, т.е. «относительной гетеропластичностью».

По видам были обнаружены достоверные различия по ширине годичного кольца: минимальные у кедра сибирского, далее кедр корейский, максимальная ширина у кедра европейского. Интересно, что эти различия начали проявляться только после 2006 года.

На рис. 2 приведены индексированные древесно-кольцевые хронологии. Корреляция между хронологиями экотипов кедра сибирского, за исключением экотипа Уренгоя, была очень высока и составляла от 0,70 до 0,94. Экотип Уренгоя был слабее всех связан с другими экотипами (коэффициенты корреляции - 0,36-0,75). Корреляция между рядами индексов экотипов кедра корейского состав- 
Таблица 2. Основные характеристики индексированных хронологий

Table 2. The basic parameters of tree-ring indices

\begin{tabular}{|c|c|c|c|c|c|c|}
\hline Экотип & 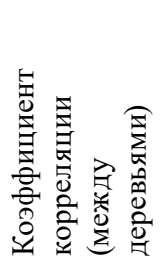 & 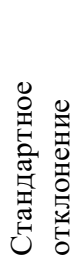 & 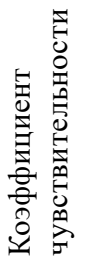 & 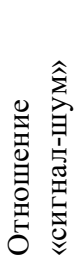 & 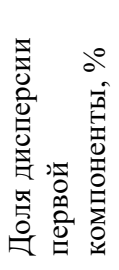 & 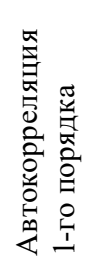 \\
\hline \multicolumn{7}{|c|}{ Кедр сибирский } \\
\hline Уренгой & $\frac{0,68}{0,66}$ & $\underline{0,29}$ & $\frac{0,25}{0,30}$ & $\frac{6,4}{5,9}$ & 77,6 & $\frac{0,29}{-0,20}$ \\
\hline Ноябрьск & $\underline{0,71}$ & $\begin{array}{l}0,26 \\
0,22\end{array}$ & $\frac{0,33}{0,28}$ & $\frac{10,0}{7,2}$ & 72,1 & $\frac{-0,13}{-0,23}$ \\
\hline Стрежевой & $\frac{0,67}{0,72}$ & $\frac{0,24}{0,24}$ & $\frac{0,26}{0,26}$ & $\frac{6,1}{7,5}$ & 81,1 & $\underline{0,09}$ \\
\hline Тайшет & $\frac{0,73}{0,65}$ & $\underline{0,24}$ & $\frac{0,30}{0,29}$ & $\frac{11,0}{7,3}$ & 71,1 & $\frac{-0,10}{-0,09}$ \\
\hline Невьянск & $\frac{0,56}{0,59}$ & $\frac{0,20}{0,20}$ & $\frac{0,24}{0,25}$ & $\frac{3,9}{4,4}$ & 70,2 & $\frac{0,03}{-0,10}$ \\
\hline Виссарионов бор & $\frac{0,66}{0,63}$ & $\frac{0,23}{0,21}$ & $\frac{0,28}{0,27}$ & $\frac{5,9}{5,1}$ & 72,8 & $\frac{-0,11}{-0,17}$ \\
\hline \multicolumn{7}{|c|}{ Кедр корейский } \\
\hline Известковый & $\frac{0,82}{0,82}$ & $\frac{0,34}{0,30}$ & $\frac{0,34}{0,36}$ & $\frac{13,9}{13,4}$ & 85,7 & $\frac{-0,007}{0,24}$ \\
\hline Пивань & $\frac{0,82}{0,82}$ & $\frac{0,25}{0,23}$ & $\begin{array}{l}0,27 \\
0,27\end{array}$ & $\begin{array}{l}9,1 \\
9,0\end{array}$ & 87,6 & $\frac{0,14}{-0,04}$ \\
\hline Горный & $\frac{0,84}{0,84}$ & $\frac{0,30}{0,29}$ & $\frac{0,31}{0,34}$ & $\frac{16,1}{15,6}$ & 86,7 & $\frac{0,22}{0,03}$ \\
\hline \multicolumn{7}{|c|}{ Кедр европейский } \\
\hline Тренто & $\frac{0,73}{0,69}$ & $\underline{0,34}$ & $\frac{0,33}{0,32}$ & $\frac{7,9}{6,6}$ & 77,9 & $\frac{0,08}{-0,08}$ \\
\hline
\end{tabular}

Примечание: в знаменателе характеристики стандартных хронологий, в числителе - остаточных.

ляла более 0,85 . Несмотря на кажущуюся близость кедра европейского к кедру корейскому (по величине прироста), он был теснее связан с кедром сибирским $(0,73)$, чем с кедром корейским $(0,62)$, а если убрать из расчетов средних индексов кедра сибирского экотипы Уренгой и Стрежевой, то эта связь будет еще теснее $(0,85)$.

Несмотря на отсутствие несовместимости между привоем и подвоем у экотипов кедра сибирского (гомопластические прививки), наблюдалось незначительное превышение прироста подвоя над привоем во второй половине анализируемого диапазона роста (с 2010 г., рис. 3). У прививок кедра корейского на кедр сибирский (гетеропластические прививки) наблюдался заметный визуально эффект «бутылочного горлышка» - превышение диаметра подвоя над диаметром привоя (примерно на 30 \%). Это хорошо видно по накопленным значениям прироста (рис. 3). Накопительная динамика прироста кедра европейского (привой) полностью совпадала с динамикой прироста кедра сибирского (подвой).

Анализ связи остаточных индексов прироста с температурой и осадками у экотипов 

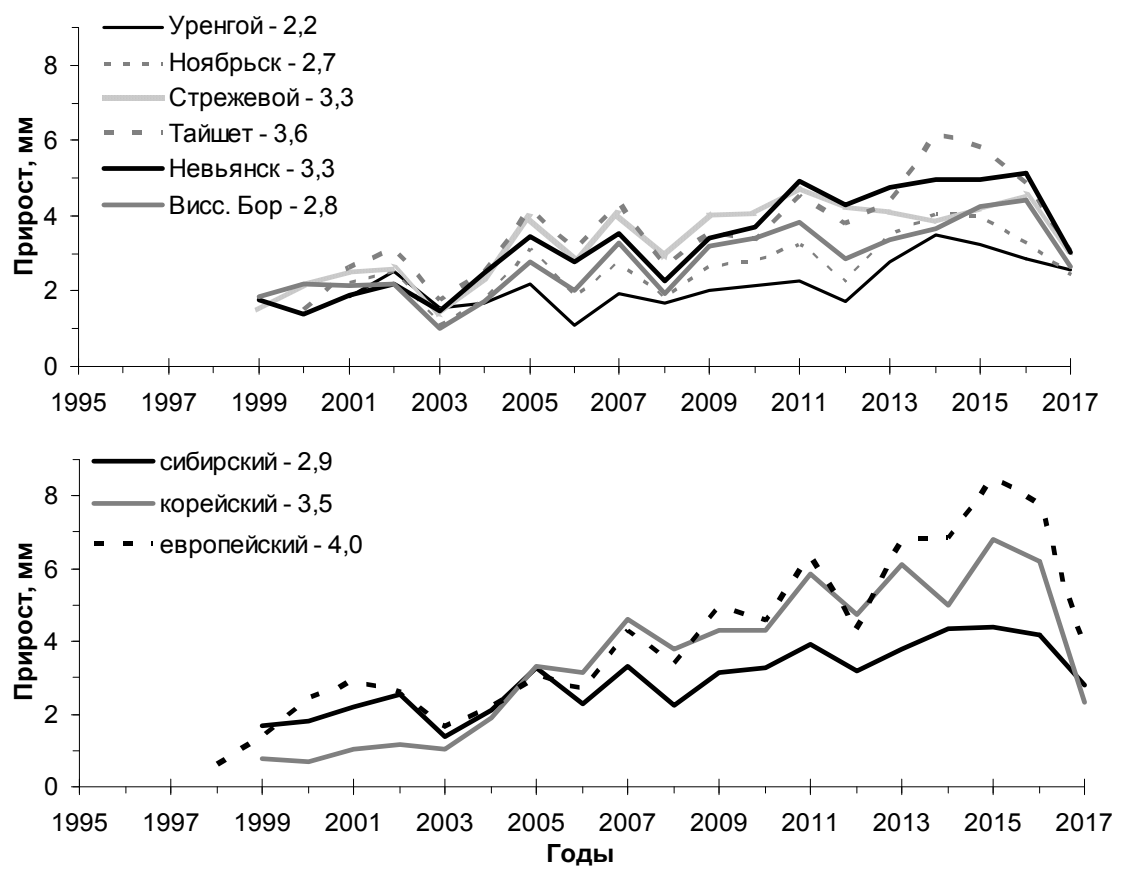

Рис. 1. Радиальный рост различных экотипов кедра сибирского (вверху) и различных видов (внизу). Цифры в легендах обозначают среднемноголетнюю величину радиального прироста в мм

Fig. 1. Tree ring widths of different Siberian stone pine ecotypes (top), Korean stone pine and Swiss stone pine (bottom). The numbers in legends represent the annual mean tree-ring width, $\mathrm{mm}$
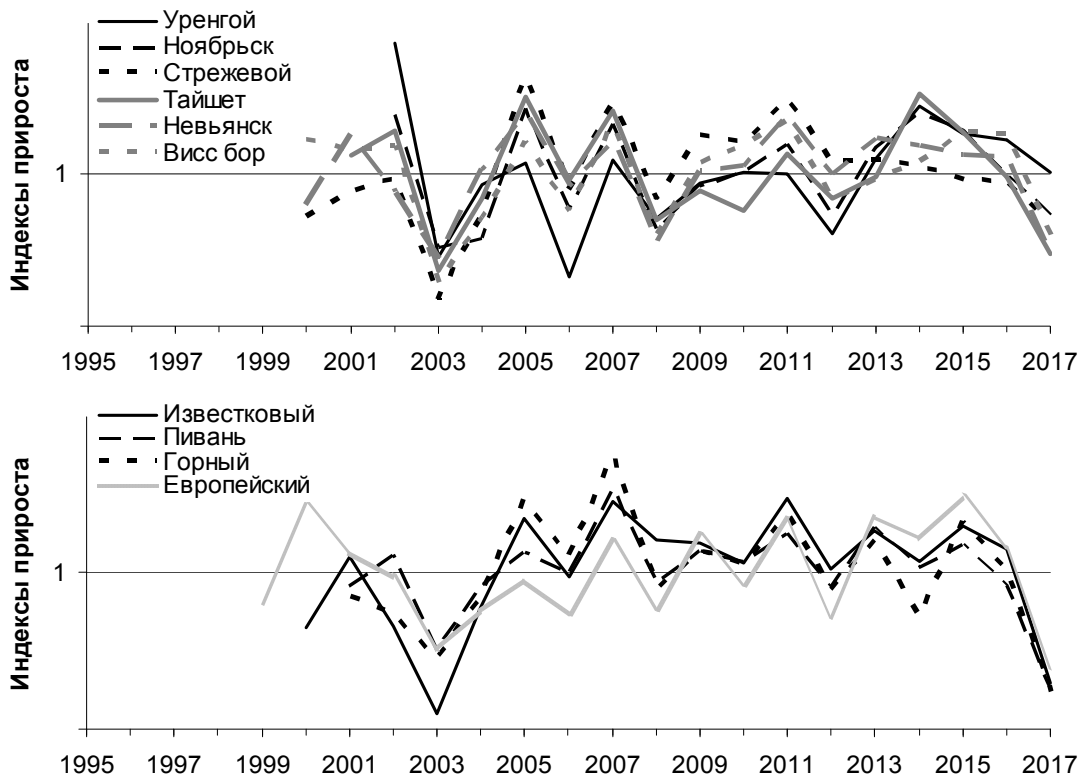

Рис. 2. Индексированные остаточные хронологии экотипов кедра сибирского (вверху), корейского и европейского (внизу)

Fig. 2. Residual indexed chronologies of Siberian stone pine ecotypes (top), Korean stone pine and Swiss stone pine (bottom) 

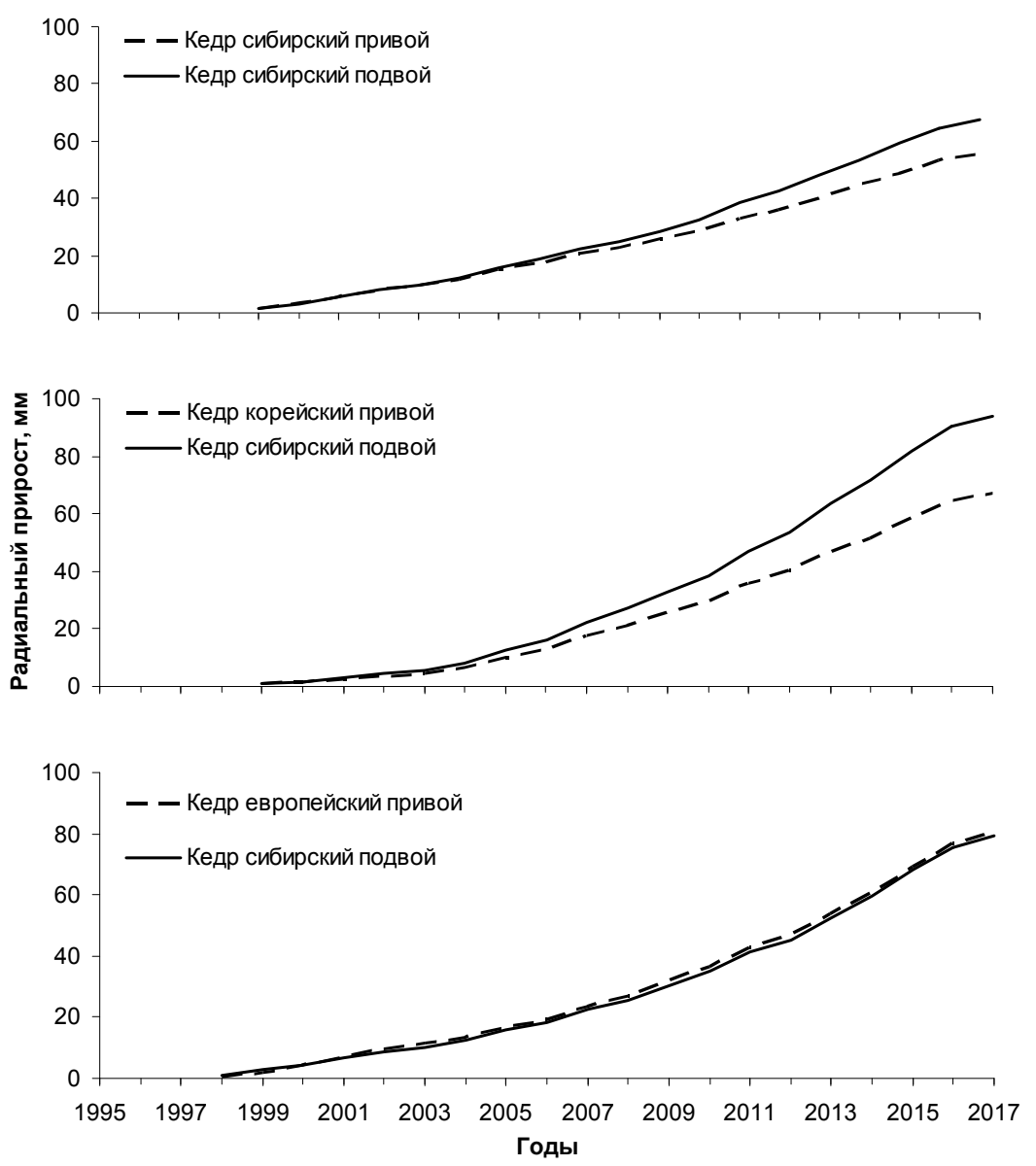

Рис. 3. Показатели радиального прироста (накопленные значения) привоя и подвоя (среднее по видам)

Fig. 3. Tree ring width (accumulated values) of the graft and rootstock (species average)

кедра сибирского выявил следующее (рис. 4). Была отмечена достоверная положительная связь с температурой апреля и осадками мая и июля и близкая к достоверной отрицательная связь с температурой июня. Слегка выбивался из этой картины только экотип Уренгоя (слабая связь с апрелем и июлем, но близкая к достоверной связь с осадками июня и температурой августа).

У кедра корейского и европейского наблюдалась похожая картина, но есть вариации (рис. 5). Кедр европейский в этом отношении был больше похож на сибирский: положительная связь с температурой апреля и осадками мая и июля (последняя близка к достоверной) и тенденция к отрицательной связи с температурой мая-июня и к положительной связи с осадками августа. Связь индексов прироста экотипов кедра корейского с температурой совпадала с выявленной для кедра европейского. По осадкам кедр европейский не показывал достоверных связей, а только тенденцию к положительной связи с осадками июля-августа. В целом наблюдались две общие связи, достоверные для всех видов: положительные с температурой апреля и осадками июля.

\section{Обсуждение}

У кедра сибирского прирост ширины годичного кольца уменьшался от южного эко- 


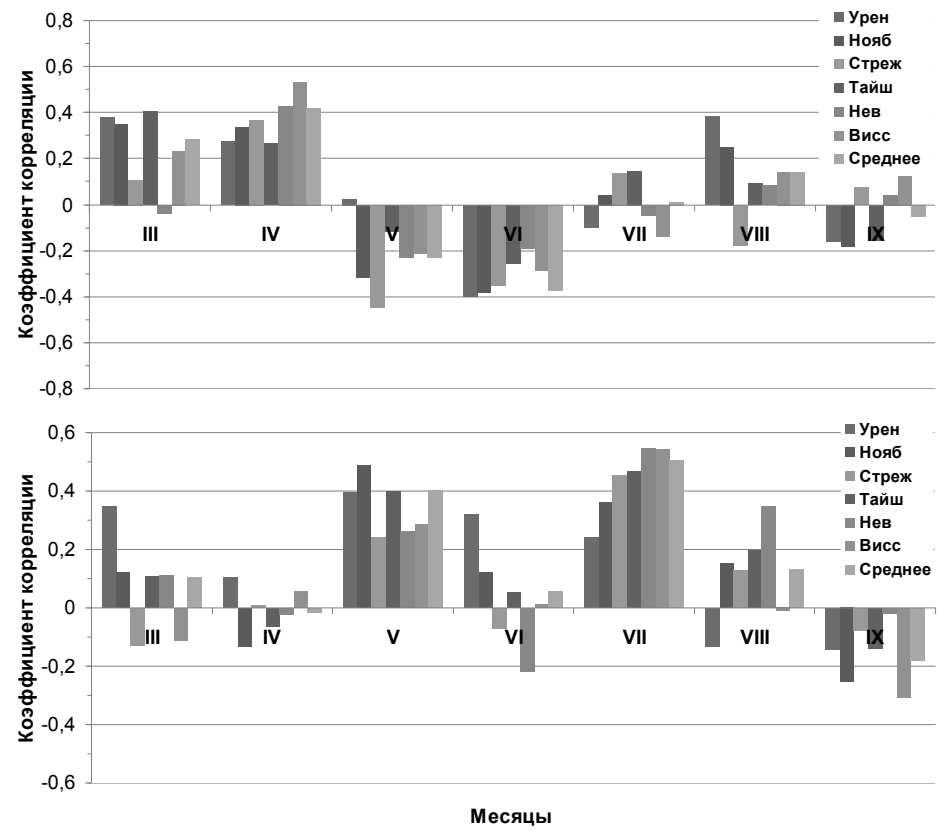

Рис. 4. Связь среднемесячной температуры (вверху) и осадков (внизу) с остаточными индексами прироста у экотипов кедра сибирского. Коэффициенты значимы при r $>0,4$

Fig. 4. Correlation coefficients relating monthly mean temperature (top) and precipitation (bottom) to the residual tree-ring indices of Siberian stone pine ecotypes. Coefficients are significant at $r>0.4$

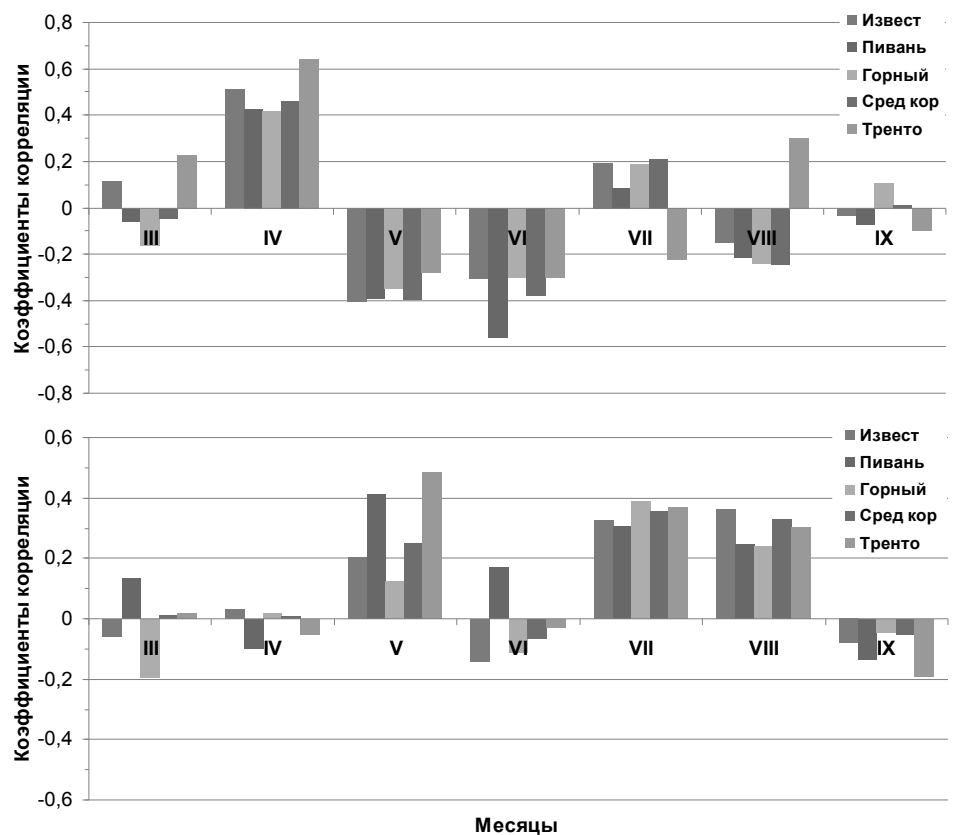

Рис. 5. Связь среднемесячной температуры (вверху) и осадков (внизу) с остаточными индексами прироста у экотипов кедра корейского и европейского. Коэффициенты значимы при $\mathrm{r}>0,4$

Fig. 5. Correlation coefficients relating monthly mean temperature (top) and precipitation (bottom) to the residual tree-ring indices of Korean and Swiss stone pine ecotypes. Coefficients are significant at $r>0.4$ 
типа к северному, за исключением экотипа Виссарионов бор, что связано, скорее всего, с резким отличием возраста материнских деревьев данного экотипа от других. Материнские деревья, давшие начало клонам, были в 1,5-3 раза старше материнских деревьев из других экотипов, поэтому морфологические особенности клонов могли быть следствием явления циклофизиса, когда привой сохраняет некоторые онтонетические особенности материнского дерева (Olesen, 1978). Циклофизис хорошо известен у плодовых деревьев и активно используется для получения деревьев с интенсивным плодоношением (Oliveira, Browning, 1993; Snowball et al., 1994). У хвойных видов это явление изучено гораздо меньше, но было обнаружено также довольно давно. Так, у Pinus elliottii клоны от старых материнских деревьев росли гораздо медленнее и меньше ветвились по сравнению с клонами молодых деревьев (Parker et al., 1998). У P. radiata укореняемые черенки от материнских деревьев разного возраста значительно различались по анатомическим характеристикам хвои и ствола, а также по экспрессии генов (Alvarez et al., 2016).

В целом, прямая связь роста по высоте и диаметру с теплообеспеченностью вегетационного периода в районе происхождения экотипа у большинства хвойных видов была выявлена как в природных древостоях (Makinen et al., 2003; Takahashi, 2006), так и в географических культурах (Ирошников, 1977; Oleksyn et al., 2001; Lesser, Parker, 2004), в том числе у кедра сибирского (Кузнецова, 2007; Жук, 2010, 2014). Однако уровень внутривидовой изменчивости может существенно различаться. Например, в экспериментах ex situ у Pinus sylvestris (Oleksyn et al., 1998), Picea glauca (Lu et al., 2014) и Pinus sibirica (Zhuk, Goroshkevich, 2018) от северного к южному экотипу средний градиент по высоте дерева составлял 3,5, 6 и $10 \%$ на $1^{\circ}$ широты соответственно. Различия по радиальному росту между клонами кедра сибирского, кедра корейского и кедра европейского в нашей работе появились при достижении ими возраста 10 лет. Самым высоким уровнем внутривидовой дифференциации среди них обладал кедр сибирский, тогда как дифференциацию кедра европейского оценить не удалось вследствие отсутствия необходимой выборки экотипов. Различия между видами были довольно существенны. В среднем радиальный прирост у кедра европейского был почти в 2 раза больше, чем у кедра сибирского. Хотя радиальный прирост у южного экотипа кедра сибирского мало уступал приросту кедра европейского, у северных экотипов он был самым слабым из всех. Кедр корейский имел промежуточные значения среднего радиального роста среди трех видов. В природе длина побегов у кедра корейского больше, чем у кедра сибирского (Горошкевич, Попов, 2004), эти же межвидовые различия по росту сохранялись и в условиях клонового архива. Превышение по радиальному росту кедра европейского над остальными видами, скорее всего, временное, так как его значительные отличия от корейского наблюдались только в три года - 2014, 2015 и 2016 гг.

Несмотря на значительные различия в ширине годичного кольца как между экотипами, так и между видами, возрастной тренд и погодичная динамика прироста показали слабые различия. То есть погодичная изменчивость прироста в большей степени зависела от местных условий среды и климата, чем от места происхождения материнских деревьев. Аналогичные факты были установлены для географических культур Pinus banksiana в Канаде (Savva et al., 2007).

Несовместимость привоя и подвоя характерна для гетеропластических прививок раз- 
ных видов (Jayawickrama et al., 1991). В этом случае привой и подвой влияют друг на друга, и их рост определенным образом изменяется в зависимости от видовой принадлежности. Например, у прививок кедра сибирского на сосну обыкновенную радиальный рост подвоя был существенно меньше по сравнению с непривитыми деревьями (Дарикова и др., 2013). В связи со значительными различиями по темпам роста кедра корейского и кедра сибирского у всех прививок первого на второй наблюдались различия по радиальным приростам. Хотя кедр сибирский генетически более близок к кедру корейскому, чем к сосне обыкновенной, несовместимость привоя и подвоя у них проявлялась так же ярко, но в другом направлении. Привои кедра корейского были существенно тоньше подвоев кедра сибирского, при этом по сравнению с ними гомопластические прививки кедра сибирского имели меньший радиальный рост. Это свидетельствует о том, что кедр корейский значительно усилил радиальный рост подвоя кедра сибирского. Хотя видимой несовместимости гомопластических прививок кедра сибирского ранее не наблюдалось (Zhuk, Goroshkevich, 2018), мы обнаружили небольшое превышение радиального роста подвоя над привоем. Несовместимости кедра европейского с кедром сибирским не случалось вообще. Данные виды очень близки между собой генетически (Politov et al., 2008; Höhn et al., 2009), что позволяет ряду авторов считать их подвидами (Goncharenko et al., 1992). Видимо, в связи с этим было бы правильно считать эти прививки гетеропластическими лишь условно.

Все три вида показали достоверную положительную связь остаточных индексов прироста с температурой апреля и осадками июля. Для гетеропластических прививок данных видов, выращенных в красноярской лесостепи, также была характерна положительная связь индексов прироста привоев с температурой апреля (Савва и др., 2004), тогда как при удалении из анализа компоненты, представляющей собой климатическую реакцию контрольных деревьев, индексы прироста привоев положительно коррелировали с температурой осеннего периода предыдущего года и отрицательно - с температурой апреля-мая текущего года роста (Дарикова и др., 2013). Повышение температуры апреля ускоряет таяние снежного покрова, приближая начало вегетационного периода. Поскольку объекты исследования располагаются в «чистом поле» и пока еще не сформировали полноценное насаждение со своим микроклиматом, с началом вегетационного периода (до и на протяжении его) большую роль начинают играть осадки, предотвращая засуху и усиливая рост. На кедр корейский большое влияние оказывают также весенние заморозки, которые в нашей работе не учитывались.

\section{Заключение}

Клоны кедра сибирского, кедра корейского и кедра европейского существенно различались по радиальному росту по достижении ими 10-летнего возраста. Наибольшим уровнем внутривидовой изменчивости обладал кедр сибирский. Между собой виды также значительно различались по средней величине годичного прироста. Кедр сибирский обладал наименьшими показателями радиального роста, кедр корейский имел больший прирост, а кедр европейский демонстрировал наибольший рост. Погодичная изменчивость прироста показала слабые различия как между экотипами, так и между видами. Несовместимость привоя и подвоя была очень выражена у прививок кедра корейского на кедр сибирский и почти не выражена у гомопластических прививок. Привой и подвой во всех случаях ока- 
зывали друг на друга взаимное влияние. Bсе три вида имели достоверную положительную связь остаточных индексов прироста с температурой апреля и осадками июля.

\section{Список литературы}

Ваганов Е.А., Шиятов С.Г., Мазепа В.С. (1996) Дендроклиматические исследования в Урало-Сибирской Субарктике. Новосибирск, Наука, 246 с. [Vaganov E.A., Shiyatov S.G., Mazepa V.S. (1996) Dendroclimatic study in Ural-Siberian Subarctic. Moscow, Nauka, 246 p. (in Russian)]

Горошкевич С.Н., Попов А.Г. (2004) Структура побегов у российских видов Pinus из группы Cembrae (Pinaceae). Ботанический журнал, 89(7): 1077-1092 [Goroshkevich S.N., Popov A.G. (2004) Shoot morphological structure of the Russian Pinus species from the group Cembrae (Pinaceae). Botanical Journal [Botanicheskii Zhurnal], 89(7): 1077-1092 (in Russian)]

Дарикова Ю.А., Ваганов Е.А., Кузнецова Г.В., Грачев А.М. (2013) Радиальный рост прививок кедровых сосен (Pinaceae) в условиях красноярской лесостепи. Журнал Сибирского Федерального Университета. Биология, 1(6): 3-17 [Darikova J.A., Vaganov E.A., Kuznetsova G.V., Grachev A.M. (2013) Radial growth of Siberian pine heterografts (Pinaceae) in Krasnoyarsk foreststeppe. Journal of Siberian Federal University. Biology, 1(6): 3-17 (in Russian)]

Жук Е.А. (2010) Изменчивость структуры побега кедра сибирского (Pinus sibirica Du Tour) вдоль широтного профиля: исследование ex situ. Хвойные бореальной зоны, 27(1-2): 6872 [Zhuk E.A. (2010) Variation of the Siberian stone pine (Pinus sibirica Du Tour) shoot structure along the latitudinal transect: analysis ex situ. Conifers of the Boreal Area [Khvoinye boreal'noi zony], 27(1-2): 68-72 (in Russian)]

Жук Е.А. (2014) Рост клонов кедра сибирского различного географического происхождения на юге Томской области. Вестник Московского государственного университета леса - Лесной вестник, 18(1): 101-105 [Zhuk E.A. (2014) Growth of Siberian stone pine clones having different geographical origin in the south of Tomskaya oblast. Bulletin of Moscow State Forest University Forestry Bulletin [Vestnik Moskovskogo gosudarstvennogo universiteta lesa - Lesnoi vestnik], 18(1): 101-105 (in Russian)]

Ирошников А.И. (1977) Географические культуры хвойных в Сибири. Географические культуры и плантации хвойных в Сибири. Новосибирск, Наука, с. 3-110 [Iroshnikov A.I. (1977) Geographical provenance tests of Siberian conifers. Geographical cultures and plantations of conifers in Siberia. Novosibirsk, Nauka, p. 3-110 (in Russian)]

Кузнецова Г.В. (2007) Опыт создания клоновой плантации кедровых сосен в Красноярской лесостепи. Хвойные бореальной зоны, 24(2-3): 217-224 [Kuznetsova G.V. (2007) The experience of the creation of a clone plantation of Siberian pine in Krasnoyarsk forest steppe. Conifers of the Boreal Area [Khvoinye boreal'noi zony], 24(2-3): 217-224 (in Russian)]

Кузнецова Г.В., Дарикова Ю.А., Савва Ю.В., Ваганов Е.А., Грачев А.М. (2010) Прививки кедровых сосен как объект исследований. Хвойные бореальной зоны, 27(3-4): 312-316 [Kuznetsova G.V., Darikova J.A., Savva J.V., Vaganov E.A., Grachev A.M. (2010) The grafts of stone pines as a research object. Conifers of the Boreal Area [Khvoinye boreal'noi zony], 27(3-4): 312-316 (in Russian)]

Савва Ю.В., Яковлева А., Ваганов Е.А., Кузнецова Г.В. (2004) Климатическая реакция радиального роста прививок кедра сибирского на подвоях сосны в лесостепи Средней Сиби-

$$
-271-
$$


ри. Лесное хозяйство, 5: 36-38 [Savva J.V., Yakovleva A., Vaganov E.A., Kuznetsova G.V. (2004) Climatic signals in tree rings of Siberian stone pine grafts on Scots pine rootstock in the Middle Siberia forest-steppe. Forestry [Lesnoe khozyaistvo], 5: 36-38 (in Russian)]

Шиятов С.Г. (1986) Дендрохронология верхней гранищы леса на Урале. М., Наука, 136 с. [Shiyatov S.G. (1986) Dendrochronology of upper forest line in the Urals. Moscow, Nauka, 136 p. (in Russian)]

Alvarez C., Valledor L., Sáez P., Hasbún R., Sánchez-Olate M., Cañal M.J., Ríos D. (2016) Changes in gene expression in needles and stems of Pinus radiata rootstock plants of different ontogenic age. American Journal of Plant Sciences, 7: 1205-1216

Amodei T., Guibal F., Fady B. (2013) Relationships between climate and radial growth in black pine (Pinus nigra Arnold ssp. salzmannii (Dunal) Franco) from the south of France. Annals of Forest Science, 70(1): 41-47

Bhuta A.A.R., Kennedy L.M., Pederson N. (2009) Climate-radial growth relationships of northern latitudinal range margin longleaf pine (Pinus palustris P. Mill.) in the Atlantic Coastal Plain of southeastern Virginia. Tree-Ring Research, 65(2): 105-116

Bogino S., Fernández Nieto M.J., Bravo F. (2009) Climate effect on radial growth of Pinus sylvestris at its southern and western distribution limits. Silva Fennica, 43(4): 609-623

Chuine I., Rehfeldt G.E., Aitken S.N. (2006) Height growth determinants and adaptation to temperature in pines: a case study of Pinus contorta and Pinus monticola. Canadian Journal of Forest Research, 36 (5): 1059-1066

Cook E.R. (1985) A time series analysis approach to tree-ring standardization: Ph.D. Dissertation. Tucson, AZ, University of Arizona, $171 \mathrm{p}$.

Douglass A.E. (1919) Climatic cycles and tree growth: A study of the annual rings of trees in relation to climate and solar activity. Vol. 1. Washington, Carnegie Inst., $127 \mathrm{p}$.

Goncharenko G.G., Padutov V.E., Silin A. (1992) Population structure, gene diversity, and population differentiation in natural populations of Cedar pines (Pinus subsect. Cembrae, Pinaceae) in the USSR. Plant Systematics and Evolution, 182(3-4): 121-134

Höhn M., Gugerli F., Abran P., Bisztray G., Buonamici A., Cseke K., Hufnagel L., QuintelaSabaris C., Sebastiani F., Vendramin G.G. (2009) Variation in the chloroplast DNA of Swiss stone pine (Pinus cembra L.) reflects contrasting post-glacial history of populations from the Carpathians and the Alps. Journal of Biogeography, 36(9): 1798-1806

Holmes R.L. (1983) Computer-assisted quality control in tree-ring dating and measurements. Tree-Ring Bulletin, 43: 69-78

Holmes R.L. (1992a) Program COFECHA: Version 3. Tuscon, Laboratory of tree-ring research, University of Arizona

Holmes R.L. (1992b) Program CRONOL. Tuscon, Laboratory of tree-ring research, University of Arizona

Isik K., Isik F., Lee S.J. (1999) Genetic variation in Pinus brutia Ten. in Turkey: I. growth, biomass and stem quality traits. Forest Genetics, 6(2): 89-99

Jayawickrama K.J.S., Jett J.B., McKeand S.E. (1991) Rootstock effects in grafted conifers: A review. New Forests, 5(2): 157-173 
Lesser M.R., Parker W.H. (2004) Genetic variation in Picea glauca for growth and phenological traits from provenance tests in Ontario. Silvae Genetica, 53(4): 141-148

Lu P., Parker W.H., Cherry M., Colombo S., Parker W.C., Man R., Roubal N. (2014) Survival and growth patterns of white spruce (Picea glauca [Moench] Voss) rangewide provenances and their implications for climate change adaptation. Ecology and Evolution, 4(12): 2360-2374

Makinen H., Nöjd P., Kahle H.-P., Neumann U., Tveite B., Mielikäinen K., Röhle H., Spiecker H. (2003) Large-scale climatic variability and radial increment of Picea abies (L.) Karst. in central and northern Europe. Trees - Structure and Function, 17(2): 173-184

McLane S.C., Daniels L.D., Aitken S.N. (2011) Climate impacts on lodgepole pine (Pinus contorta) radial growth in a provenance experiment. Forest Ecology and Management, 262(2): 115-123

Methods of dendrochronology: Applications in the environmental sciences (1990) Cook E.R., Kairukstis L.A. (eds.) Dordrecht, Boston, London, 394 p.

Oleksyn J., Tjoelker M.G., Reich P.B. (1998) Growth and physiology of Picea abies populations from elevational transects: common garden evidence for altitudinal ecotypes and cold adaptation. Functional Ecology, 12(4): 573-590

Oleksyn J., Reich P.B., Tjoelker M.G., Chalupka W. (2001) Biogeographic differences in shoot elongation pattern among European Scots pine populations. Forest Ecology and Management, 148(1-3): $207-220$

Olesen P.O. (1978) On cyclophysis and topophysis. Silvae Genetica, 27(5): 173-178

Oliveira C.M., Browning G. (1993) Studies on the induction of flowering in juvenile Prunus avium L. Journal of Horticultural Science, 68(5): 731-739

Parker S.R., White T.L., Hodge G.R., Powell G.L. (1998) The effects of scion maturation on growth and reproduction of grafted slash pine. New Forests, 15(3): 243-259

Pfeifer K., Kofler W., Oberhuber W. (2005) Climate related causes of distinct radial growth reductions in Pinus cembra during the last 200 yr. Vegetation History and Archaeobotany, 14(3): $211-220$

Politov D.V., Belokon M.M., Belokon Yu.S. (2008) Allozyme variation in Pinus cembra and P. sibirica: differentiation between populations and species. Annals of Forest Research, 51(1): 143-144

Pompa-García M., Cerano-Paredes J., Fuléa P.Z. (2013) Variation in radial growth of Pinus cooperi in response to climatic signals across an elevational gradient. Dendrochronologia, 31(3): 198-204

Rinn F. (1996) TSAP V3.5. Computer program for tree-ring analysis and presentation. Heidelberg, Frank Rinn Distribution, 264 p.

Savva Y., Denneler B., Koubaa A., Tremblay F., Bergeron Y., Tjoelker M.G. (2007) Seed transfer and climate change effects on radial growth of jack pine populations in a common garden in Petawawa, Ontario, Canada. Forest Ecology and Management, 242(2-3): 636-647

Savva Y., Bergeron Y., Denneler B., Koubaa A., Tremblay F. (2008) Effect of interannual climate variations on radial growth of jack pine provenances in Petawawa, Ontario. Canadian Journal of Forest Research, 38(3): 619-630

Snowball A.M., Halligan E.A., Warrington I.J., Mullins M.G. (1994) Phase change in citrus: Growth and flowering of citrus seedlings from thirteen genetically diverse seedling families. Journal of Horticultural Science, 69(1): 141-148 
Takahashi K. (2006) Shoot growth chronology of Alpine Dwarf pine (Pinus pumila) in relation of shoot size and climatic conditions: a reassessment. Polar Bioscience, 19: 123-132

Zhuk E.A., Goroshkevich S.N. (2018) Growth and reproduction in Pinus sibirica ecotypes from Western Siberia in a common garden experiment. New Forests, 49(2): 159-172 